\title{
Gemeinschaft and Gesellschaft in Cooperatives
}

\author{
Jerker Nilsson and George Hendrikse
}

\begin{tabular}{|l|l|}
\hline \multicolumn{2}{|l|}{ ERIM REPORT SERIES RESEARCH IN MANAGEMENT } \\
\hline ERIM Report Series reference number & ERS-2009-059-ORG \\
\hline Publication & December 2009 \\
\hline Number of pages & 15 \\
\hline Persistent paper URL & http://hdl.handle.net/1765/17528 \\
\hline Email address corresponding author & ghendrikse@rsm.nl \\
\hline Address & Erasmus Research Institute of Management (ERIM) \\
& RSM Erasmus University / Erasmus School of Economics \\
& Erasmus Universiteit Rotterdam \\
& P.O.Box 1738 \\
& 3000 DR Rotterdam, The Netherlands \\
& Phone: + 31 10 408 1182 \\
& Fax: + 3110 408 9640 \\
& Email: info@erim.eur.nl \\
& Internet: $\quad$ www.erim.eur.nl \\
\hline
\end{tabular}

Bibliographic data and classifications of all the ERIM reports are also available on the ERIM website: www.erim.eur.nl 


\section{ERASMUS RESEARCH INSTITUTE OF MANAGEMENT}

\section{REPORT SERIES}

\section{RESEARCH IN MANAGEMENT}

\begin{tabular}{|l|l|}
\hline ABSTRACT AND KEYWORDS \\
\hline Abstract & $\begin{array}{l}\text { A cooperative business consists of a cooperative society and a cooperative business firm. The } \\
\text { society of members intends to control the business in such a way as to focus the business } \\
\text { operations on its interests. The two organizational units tend, however, to follow different } \\
\text { behavioral logics. Borrowing some core concepts from classical sociology, Gemeinschaft norms } \\
\text { rule ruling within the membership, while Gesellschaft norms dominate the business firms. } \\
\text { Thereby it may be difficult to accomplish alignment between the membership organization and } \\
\text { the business organization in order to be competitive. This paper addresses the difficulties of } \\
\text { following the different logics by exploring Gemeinschaft and Gesellschaft within agricultural } \\
\text { cooperatives with a focus on the membership logics. }\end{array}$ \\
\hline Free Keywords & cooperative, membership, gemeinschaft, gesellschaft, alignment \\
\hline Availability & $\begin{array}{l}\text { The ERIM Report Series is distributed through the following platforms: } \\
\text { Academic Repository at Erasmus University (DEAR), DEAR ERIM Series Portal } \\
\text { Social Science Research Network (SSRN), SSRN ERIM Series Webpage } \\
\text { Research Papers in Economics (REPEC), REPEC ERIM Series Webpage }\end{array}$ \\
\hline Classifications & $\begin{array}{l}\text { The electronic versions of the papers in the ERIM report Series contain bibliographic metadata } \\
\text { by the following classification systems: } \\
\text { Library of Congress Classification, (LCC) LCC Webpage } \\
\text { Journal of Economic Literature, (JEL), JEL Webpage } \\
\text { ACM Computing Classification System CCS Webpage } \\
\text { Inspec Classification scheme (ICS), ICS Webpage }\end{array}$ \\
\hline
\end{tabular}




\title{
Gemeinschaft and Gesellschaft in Cooperatives
}

\author{
Jerker Nilsson ${ }^{*}$ and George Hendrikse ${ }^{\dagger}$
}

* Department of Economics, Swedish University of Agricultural Sciences, P.O. Box 7013, SE-750 07 Uppsala, Sweden, and Department of Work Science, Business Economics and Environmental Psychology, Swedish University of Agricultural Sciences, P.O. Box 53, SE-230 53 Alnarp, Sweden.

Phone: +46 186717 68; E-mail: Jerker.Nilsson@ekon.slu.se

${ }^{\dagger}$ Rotterdam School of Management, Erasmus University, P.O. Box 1738, Office T8-56, NL 3000 DR

Rotterdam, The Netherlands. 


\title{
Gemeinschaft and Gesellschaft in Cooperatives
}

\begin{abstract}
A cooperative business consists of a cooperative society and a cooperative business firm. The society of members intends to control the business in such a way as to focus the business operations on its interests. The two organizational units tend, however, to follow different behavioral logics. Borrowing some core concepts from classical sociology, Gemeinschaft norms rule ruling within the membership, while Gesellschaft norms dominate the business firms. Thereby it may be difficult to accomplish alignment between the membership organization and the business organization in order to be competitive. This paper addresses the difficulties of following the different logics by exploring Gemeinschaft and Gesellschaft within agricultural cooperatives with a focus on the membership logics.
\end{abstract}

Keywords: Cooperative, Membership, Gemeinschaft, Gesellschaft, Alignment

\section{Introduction}

A cooperative is a dual organization. It consists of a cooperative society and a business firm. The society, hierarchically organized with a board on top, owns and controls the firm. The firm exists in order to satisfy the desires of the cooperative society's members. Hence the two units are closely interlinked and mutually dependent upon each other.

At the same time the two organizational units may be quite different. The business firm operates on market conditions; hence it has to be as efficient as competing firms. The society has members who are not only businessmen, for example farmers, but also humans, which means that the society has social attributes. The interrelationships between the various members of the cooperative society and therefore also between the members and the society at large are often characterized in terms of trust, involvement, commitment, solidarity, loyalty and similar socio-psychological constructs. The literature on cooperatives abounds with treatments about cooperative ideology where also the concept of a specific cooperative value set is found (Hakelius 1996; Hogeland 2006).

This difference between cooperative societies and cooperative firms implies that there might be different behavioral logics behind the activities within the two types of units. If so there is either a risk for poor alignment between the two or that the alignment that takes place is on the conditions of one organizational unit at the expense of the other one. In any case there is a risk for inefficient operations. This may be detrimental as the two organizational units are like the two sides of the same coin. If the cooperative society is dominated by the business firm, there is a risk for members becoming uncommitted and losing their trust in the cooperative, and therefore the members reduce their trade, do not want to invest in the cooperative and refrain from controlling the firm. Similarly, if the cooperative society forces the firm to adapt to its own demands only, there is a risk that the firm does not become competitive enough. 
While an investor-owned firm (IOF) has to consider only the business logics, a cooperative firm's success is contingent on the interplay between both logics, i.e. also the social attributes of the cooperative society. Hence King (1995, p 1160 \& p 1161) states that

... efficiency considerations alone cannot be the basis for institutional design, especially in a setting of high transaction costs and increasing concentration of market power. ... [T] he primary strength of cooperatives has been in providing the infrastructure and service support systems needed to deliver and implement more technologies ...

It may be that the problems that many agricultural cooperatives have been facing recently and currently face are rooted in the difficulties to unite the logics of cooperative societies and business firms. Some cooperatives have transformed into another cooperative organizational model, for example by introducing individual ownership by the members (Nilsson and Ohlsson 2007) or by restructuring their internal organization (Bijman Hendrikse and Van Oijen 2007). Others have disappeared due to mergers or acquisitions (Chaddad and Cook 2004; Van der Krogt, Nilsson and Høst 2007). Some bankruptcies have taken place (Lang 2006). Other cooperatives have sold a part of their business activities to investors, thus getting a hybrid type of cooperative (van Bekkum and Bijman 2006). Still others have converted into investor-owned firms.

The above-mentioned development may be explained with the help of property rights theory in line with Furubotn and Pejovich (1972). As a cooperative expands in order to be competitive, there will be increasing information asymmetry between the members and the professional management. Therefore the members will experience difficulties in monitoring the firm, and the management will control the residual rights. The commercial logics of running a large and complex business firm and the social logics within the membership are not aligned.

The various organizational models may be expressed as different governance structures, i.e. different constellations of control rights and income rights (Hendrikse 2005). They vary for example depending on whether producer interests or capital interests guide the decision making and whether the decision making is centralized or decentralized. Hence, also the logics within the member organization versus within the cooperative business firm are embraced by the governance structures. Nevertheless, the question of what is included in the member interests, or the membership logics, is unresolved - what kind of logic exists as the members and the member organization evaluate the cooperative business? Hence with a well balanced governance structure, i.e. one that gives highpowered incentives to the members to monitor the firm, even large and complex cooperatives may thrive (Baron 2007).

This paper addresses the logics within the memberships of agricultural cooperatives. The aim of the study is to explore the logics that may be found within cooperative memberships, especially pinpointing the problems that might result in terms of poor alignment with the logics within the cooperative business firms. 
The classification of logics used here is borrowed from classical sociology (Tönnies 1957). Gemeinschaft expresses human relationships characterized by closeness, kinship and friendship. Gesellschaft is a type of interaction that humans have with anonymous others. It is evident that these two logics vary considerably because agricultural cooperatives are very different from one another. They are found in different industries, different countries and cultures, and different time periods. For this sake the empirical basis for this study comprises several agricultural industries and different countries. Still, the findings can only be indicative.

The paper is structured as follows. Section 2 reports from six empirical studies within cooperative memberships, all indicating that the social forces are strong. The cases cover several countries and several agricultural industries. Following this is an account of a classical approach to explain different types of human interaction (or logics), for example the processes within the cooperative society and within the cooperative business firm. The subsequent section 4 is an analysis of the six empirical studies in light of the different logics of human interaction. Some conclusions for future research on cooperatives are drawn.

\section{Case studies}

\subsection{Member motive variety}

Member behavior in agricultural cooperatives has been subject to research in a large number of empirical studies. These studies report about farmers' motivational factors, attitudes, choice of business partners, and other behavioral constructs. In general these studies reveal that member behavior is complex and difficult to forecast.

A selection of studies is presented here. The choice of studies is based on a few conditions. First, they should be recent. Second, they should present a variety of member behavior, i.e. different agricultural industries and different countries. Hence the six studies represent cooperatives in five countries, operating in five agricultural industries. All of them present the social forces within the membership - how members look upon the cooperatives as trading partners and their willingness to be involved in the cooperatives.

\section{Swedish forest owners}

In a study of Swedish forest owners' choice between cooperative and investor-owned business partners Enander, Melin and Nilsson (2009) found that the forest owners often base themselves on personal relations to the representatives of the buying firms. Because the ownership of forest land represents substantial amounts of capital, the forest owners should reasonably be keen to get the highest possible price for their timber. It should be noted that forestry is regarded as an agricultural industry as a large share of Sweden's forest land is owned by farmers. 
One possible explanation for the forest owners' behavior is that the calculation of prices is a complicated matter because no two trees are identical. Likewise, the forestry cooperatives and the investor-owned processors apply different pricing principles, whereby the forest owners have difficulties in comparing the prices. Moreover, while the investor-owned processors pay a flat price, the major cooperative also pays patronage refunds, a dividend that is difficult to know beforehand, as well as bonus shares.

Some forest owners even regard the buying firms' representatives as personal friends even though they must reasonably understand that these persons' interests are directly opposite to their own interests. A possible reason may be that conducting forestry operations involves considerable complexities for many owners so they are in need of assistance and advice.

An outside observer would believe that the forest owners, due to the difficulties in assessing the two optional buyer categories, would discuss with each other in order to obtain information. That is, however, not the case. On the contrary the forest owners hardly ever exchange experiences about different business partners. This is a sensitive issue and they do not want to jeopardize their relations with other forest owners.

If the forest owners are not affected by other forest owners' choice of business partners they are the more influenced by traditions. A large share of the respondents said that they have the same partner firm as their parents had. The business partners are inherited from one generation to the next.

All in all, the forest owners' behavior seems to be loaded with sentiments - about cooperative versus non-cooperative partners, relationships to the processing firms' representatives, relationships to neighboring forest owners, relationships to family, etc. When planning its operations the forestry cooperative has to take these behavioral traits into account and likewise in its running of the member organization and in all other exchange with the members.

\section{Macedonian dairy farmers}

Krstevska and Nilsson (2009) report about Macedonian dairy farmers' relationships with different types of buying firms. Diary farms in Macedonia are divided into small and large farms. The small farms have only a few cows while the large farms may have twenty or more cows. The large farmers' behavior resembles that of dairy farmers in Western Europe. The processors have cool tanker trucks, which collect the milk at the farms every second day.

The small dairy farmers are different. Their handling of the milk is purely manual and they have no cooling equipment. Even though they deliver the milk to special collection stations in the villages twice per day, the quality of the milk becomes poor (contaminated by bacteria, high amount of cells, low on protein, etc.). This milk can not be delivered to a firm that processes the raw product to any value-added products. If this were to happen, the price would be extremely low. Instead the milk is sold to small processors in the 
villages where it is mainly made into yoghurt. These small dairies pay a fixed per liter price because they have no equipment for measuring quality.

There are social connections between the smallholders so they generally inform each other about everything they do. There are, however, also strong links between the smallholders and the yoghurt producers in the villages. These links contribute to preserve the trading pattern. Hence, no development takes place. Alternatively the dairy farmers (small as well as large) could have established a cooperative firm which would advice them about how to get better milk quality and to market the milk at a higher price. Such cooperatives are, however, not established since the farmers have little trust in one another and they also lack both capital to invest in a cooperative and skills to organize it.

In conclusion, the small dairy farmers are to a large extent driven by social forces, which contribute to preserve status quo, preventing the formation of a cooperative and the improvement of milk quality and the search for alternative processing firms.

\section{Russian agricultural producers}

Another study that concerns farmers' disinterest in cooperative organizations treats Russian experiences (Golovina and Nilsson 2009). Because the agricultural producers have no tradition of cooperative business the Russian government has instituted a number of marketing and supply cooperatives. A survey among the agricultural producers shows that these top-down organized cooperatives have meager survival chances.

The population of agricultural producers is extremely heterogeneous, comprising both former kolzhoses and sovzhoses (with a few thousand hectares) and household farmers (with about one hectare on average). Hence the degree of trust within the memberships is extremely small. The cooperatives that the governmental authorities have established are about to fade away as the equity capital is being lost. The chairman of the board is often one of the very large agricultural producers, and he has not the ability to unite the very heterogeneous membership - on the contrary his interest is to promote his own interests.

\section{Members of a Swedish farm supply and grain marketing cooperative}

The board of directors of Sweden's largest agricultural cooperative faced problems as the members raised complaints about poor prices both when they bought farm inputs from the cooperative and when they sold grain to it (Nilsson, Kihlén and Norell 2009). As a result the board launched a budget-cutting program, leading to the demise of the retail chain and the decrease in the number of silos. Moreover, the member organization was remodeled. The number of local wards was reduced and larger wards were created. The number of echelons in the organizational hierarchy was reduced and the number of elected representatives became fewer. Through these measures the cooperative succeeded to cut one-tenth of its total costs whereby it could improve the prices offered to the members. 
This cost cutting process was, however, not positively received by the members. Both the silo plants and the retail outlets were the members' local connections to the cooperative. These plants had "always" existed and were important to preserve a living countryside, according to the members. The new member organization was considered to weaken the members' connection to each other and to the cooperative. A survey showed that the members had low trust in the cooperatives' leadership, and their commitment was low. Hence, the social forces within the membership and the economic interests of the members were contradictory.

Contributing to the low member commitment is the fact that this cooperative follows a specific governance structure. One-fourth of the cooperative's turnover is trade with the members - the rest is upstream and downstream activities with no connection to the farmers, also internationally. The cooperative has operations in 19 countries. The nonmember related business operations are run as a profit-maximizing business. Thanks to the profits of these downstream and upstream operations the members get extremely good return on the investments in the cooperative. Nevertheless they feel that the non-member related operations dominate the cooperative to the extent that their interests are no longer taken into account.

\section{New Zealand dairy farmers}

In 2007 the board of Fonterra, one of the world's largest dairy cooperatives, proposed that the cooperative should be partly demutualized. In order to be able to exploit market opportunities the cooperative needed more capital, and the Stock Exchange was considered to be the best capital source (Rydberg 2009). Most members were, however, opposed to this remodeling plan. There is a strong cooperative tradition in New Zealand. For most dairy farmers Fonterra is the only possible milk buyer. Hence, an opposition' was seen within the membership, and the board withdrew its proposal.

Contributing to this development is the fact that Fonterra has a "shadow board", Shareholders' Council, which worked against the proposal of the board. The Shareholders' Council enjoys the members' confidence much more than the Board. It was meant to be a "watch dog" when Fonterra was established as this cooperative would be extremely dominating in the New Zealand dairy industry.

\subsection{Alignment of member society and business firm motives}

Many studies report about similar social driving forces among cooperative members (e.g. Jensen 1990; Hansen, Morrow and Batista 2002; Bhuyan 2007; James and Sykuta 2006; Österberg and Nilsson 2009). Some state that various economic factors are important for member commitment, loyalty, and other expressions of satisfaction (Fulton and Adamowicz 1993; Gray and Kraenzle 1998). However, others state that the cooperatives' service level as well as the cooperatives' ability to offer an assured market is just as important as the price levels (Burt and Wirth 1990; Misra, Carley and Fletcher 1993), or sometimes even more important (Bravo-Ureta and Lee 1988; Cain, Toensmeyer and Ramsey 1989; Jensen 1990; Klein, Richards and Walburger 1997). 
Borgen (2001) conducted a study among members of Norwegian cooperatives. The farmers have a psychological attachment to their cooperatives. Their membership even contributes to providing "self-identification". In an investigation, covering Swedish members of agricultural cooperative within different industries Fahlbeck (2007) found that there is a preference for unallocated (collectively owned) capital. This may be interpreted as the members feeling like a collective.

Laursen (2005) found regarding different Danish cooperatives that the farmers were generally satisfied with the cooperatives, even though these are of very large size. The largest agricultural cooperatives in Denmark seem to have succeeded in preserving strong member satisfaction even though they are working on world market conditions.

\section{Gemeinschaft and Gesellschaft}

The empirical observations presented in section 2 may be analyzed in terms of Gemeinschaft and Gesellschaft. These two concepts originate from classical sociological theory, coined by the German pioneering sociologist Ferdinand Tönnies in 1887. The concepts have been translated into English as "community" and "society" (Tönnies 1957) but these terms do not cover the original German terms very well so Gemeinschaft and Gesellschaft are most often used also in English language texts.

Gemeinschaft and Gesellschaft are ideal type concepts. They may very well exist in their extreme form in real life but there is also a host of intermediary forms.

\subsection{Gemeinschaft}

Gemeinschaft implies interaction between humans who know each other more or less and, above all, who care for each other. Hence it most often concerns interaction within relatively small groups. It is typical that the group of founders of a cooperative society consists of a few individuals who are well acquainted, and thus have trust in each other. It is, however, not necessary that Gemeinschaft occurs only in small groups. The number of individuals could even be quite large, for example within a social class, where a specific class consciousness exists. Therefore, one may find Gemeinschaft also in large cooperative memberships as well as in churches and social classes.

Within a Gemeinschaft, the motivation is the individuals' Wesenwille, which has been translated into "essential will". The Gemeinschaft members are members of the group because the membership is self-evident to them. The driving force is hence almost instinctive and organic. The membership gives satisfaction in itself and is thus selffulfilling. To the extent that a member of a Gemeinschaft does no longer find his or her membership satisfactory, he or she will leave the group, and vice versa. Because of this Gemeinschaft groups tend to be homogeneous in respects that are important to the members. 
Tönnies identified two types of Gemeinschaft. One is cooperatives (Genossenschaft), which implies community between all participating actors on an equal basis. The other subgroup is authority (Herrschaft), which implies that there are natural or elected leaders within the group, for example priests within a religious community. It seems that Tönnies had sympathies for the cooperative category as the entire book has been seen as an expression of his worries about the increasing dominance of Gesellschaft formations in Germany of his time, and he hoped that the growing consumer cooperative movement was a promising development.

\subsection{Gesellschaft}

Gesellschaft concerns human interaction when the actors are unknown and anonymous to one another. Gesellschaft interaction is more likely to occur within large groups of individuals. Hence it may characterize the interaction within large cooperative memberships, including the members' attitudes towards the cooperative society and the cooperative firm. Just as the case is with Gemeinschaft, Gesellschaft is found in both large and small groups of individuals. It occurs, for example, when an individual buyer and an individual seller are negotiating with each other.

The driving force behind Gesellschaft was called Kürwille by Tönnies, or "conditional will" or "arbitrary will". It implies that the individual exhibits a calculative behavior. An individual who acts according to Kürwille separates means from ends and is thus able to choose efficient means to reach his or her goals. Hence, the behavior is future directed, purposive and instrumental.

\subsection{From Gemeinschaft to Gesellschaft}

Gemeinschaft and Gesellschaft are opposing each other. An individual who acts according to Wesenwille in a Gesellschaft setting will have problems, and vice versa. For this reason the balance between the two modes of interaction determines the degree of success of an individual or organization may get. An actor must know the balance between the two interaction types and act accordingly, or the actor must choose a setting that is suitable for a specific way of acting.

The problems of conflicting Gemeinschaft and Gesellschaft are aggravated as the two are often organizationally related to each other and thus they affect each other. This is the case of cooperative organizations, comprising both a cooperative society and a cooperative business firm. Tönnies devoted much thought to a similar relationship, namely that between the people and the state.

Many researchers, including Tönnies himself, state that the balance between the two types of human interaction is successively changing. Gesellschaft is constantly gaining ground on behalf of Gemeinschaft. This pattern could, however, not be the entire truth as that would imply that over the years all human interaction would be of the Gesellschaft type. 
The solution to this apparent paradox must reasonably be that new Gemeinschaft organizations are being established all the time, but these new establishments are so small that they are hardly visible to observers. Gemeinschaft organizations, which are successful, tend to grow whereby they take on more and more Gesellschaft attributes. For example, it is a widespread observation that cooperatives, in order to be competitive, expand and merge, and so the membership organizations become large and get bureaucracy attributes. In several Western European countries there is a wave of small newly established cooperatives as a reaction to the continuing growth of the large cooperatives. "Countervailing powers" are in operation. These newly established and small cooperatives are generally characterized by substantial Gemeinschaft.

The difficulties in preserving Gemeinschaft are the core of Michels' study of the German social democratic movement (Michels 1968 [1911]). As the Party expanded, the organization could no longer preserve its democratic ideals. Instead a small elitist group will grasp the control. Michels considered this to be an inevitable development in all democratic popular movements, and so he coined the concept "the Iron Law of Oligarchy". Michels' study has often been cited by critics of cooperative organizations.

A similar development is reported by Stryjan (1989) when he investigated the development of the Israeli kibbutzim. For this form of cooperative organization to survive, a constant "reproduction of the membership" is necessary, otherwise the Gesellschaft attributes will squeeze out the Gemeinschaft attributes. The kibbutzim are successively losing ground.

\section{Analysis}

The six studies presented above are here subject to interpretation in terms of the Gemeinschaft-Gesellschaft taxonomy. All the studies indicate that members of cooperative societies do not always behave in accordance with the assumptions of homo oeconomicus. They are rather homo sociologicus even though the border line between these two conceptions of human behavior is often diffuse.

The Russian agricultural producers would benefit from cooperative organizations, and so would the Macedonian smallholders in the dairy industry. If these actors were to behave rationally - in line with Gesellschaft norms - they could perhaps establish some cooperatives. The fact that the level of trust between the farmers is low prevents them from taking any initiative in the direction of cooperative formation. To the extent that the Russian agricultural producers and the Macedonian smallholders have good reasons for their distrust in other producers their behavior does not express Gemeinschaft behavior but rather Gesellschaft behavior. Given the conditions in these two countries it is likely that they have good reasons to doubt the trustfulness of other farmers.

The situation is more complex in Russia than in Macedonia as the Russian agricultural producers actually have cooperatives, established by the governmental administration. The fact that these cooperative were founded by governmental bodies and not by the 
producers is crucial. The producers' trust in government is strongly influenced by their experiences from the Soviet era, which is to say that the producers are due to have little sympathy for the top-down organized cooperatives. These firms are not considered to belong to the producers.

On top of this, the heterogeneity among the Russian agricultural producers is extreme, so the prospects for trust, commitment and loyalty are minimal. The producers are members because they want to reap the benefits from governmental investments in the cooperatives, not because they believe in cooperative business - actually they have very little knowledge about cooperatives. Hence, one may conclude that the Russian agricultural producers have no Gemeinschaft relation to the cooperatives. The same is true for the Macedonian small dairy farmers. Under such conditions any future for cooperative business does not exist.

The opposite condition holds true for the New Zealand dairy farmers. Being a member of Fonterra contributes to the self-identification for the dairy farmers. Contributing to this is the fact that the farmers might be in a vulnerable position if Fonterra were no longer controlled by the farmers. The cooperative tradition in New Zealand is so strong that the dairy farmers want to keep on owning and controlling Fonterra and deliver their milk to this cooperative.

The situation in the largest Swedish cooperative in the farm supply and grain marketing industry is complex. On the one hand the members demand the best possible prices from their cooperative, i.e. a Gesellschaft attribute. On the other hand they also want the cooperative to be small and personal - a Gemeinschaft demand. The two requirements do not go hand in hand. This may be an outcome of the fact that the organization is split up into two - one member-business organization and the dominating profit-maximizing organization. The logics within these two parts are widely disparate so the members do not know which kind of organization their cooperative is.

The cooperative has become so large and so diversified that the members have difficulties to identify themselves with it. It has expanded so much upstream and downstream that the members no longer understand the business activities. The international business activities are difficult for the member to apprehend.

As many of the locally based silo plants were closed and the local retail outlets were closed the members felt that the cooperative had abandoned them. These operations constituted the heart of the business, according to the members. The members demand Gemeinschaft while they are acting according to Gesellschaft norms, i. e. demanding better prices. An explanation to this seemingly contradictory behavior is that they do not understand the complex structure of the cooperative organization. The members want decentralization but the business logics require centralized decision-making.

The consequence of a complex structure of the cooperatives is also seen in the case of the forestry cooperative case. The forest owners might have the goal of getting as much as possible for their timber (Gesellschaft), but as they are bewildered by the complexities as 
concerns pricing principles they resort to socially contingent behavior (Gemeinschaft). The members might want to behave according to Gesellschaft norms but due to the difficulties of doing so they rather behave according to Gemeinschaft.

\section{Conclusions}

Behavior of cooperative business and investor-owned firms differs. Homo Sociologicus features in the orientation of members may clash with the orientation of their business firm in a cooperative, whereas this interaction will most likely be different when the business firm is investor-owned. At first glance, cooperative members, being humans of flesh and blood, may seem to behave "irrationally'. However, cooperative members behaving according to Gemeinschaft norms may also be seen as rational in a Homo Oeconomicus sense. Belonging to a social group and being influenced by social relationships may be rational for the individual. Hence, it seems that Homo Sociologicus and Homo Oeconomicus are siblings. Like so often siblings often fight but still they tend to support one another.

For this reason researchers when studying cooperatives should acknowledge the complexity that exists in cooperative businesses. The balance between Gemeinschaft (Wesenwille) and Gesellschaft (Kürwille) is hard to know beforehand, hence empirical studies are important. Therefore behavioral theories are valuable and so are empirical studies of the behavior of cooperative members and potential members.

As concerns topics for research it must be stressed that cooperative organizational models must be prioritized. The discussion above indicates that there may be conflicts between the member organization, where Gemeinschaft is often prevailing, and the cooperative business firm where Gesellschaft is due to rule. Additionally, the researchers should understand the mechanism that Gesellschaft is expanding on the behalf of Gemeinschaft in cases where Gesellschaft organizations are successful. The present trend of large cooperatives having problems to maintain their Gemeinschaft attributes is indicative. On the other hand, new and small cooperatives are continuously being established, based on Gemeinschaft conditions.

Researchers must find ways whereby the members' quest for Gemeinschaft may be balanced with their Gesellschaft relationship to the co-operative (incentive alignment). Each cooperative organizational model implies different combinations of Gemeinschaft and Gesellschaft (incentive structures). The issue of centralization versus decentralization of decision making is essential. Which effects do different governance structures have for the cooperative members?

\section{References}


Baron, M-L. (2007). Defining the Frontiers of the Firm through Property Rights Allocation: The Case of the French Retailer Cooperative Leclerc, Review of Social Economy, 65, 293-317.

Bhuyan, S. (2007). The 'people' factor in cooperatives: An analysis of members' attitudes and behavior. Canadian Journal of Agricultural Economics, 55, 275-298.

Bijman, J, Hendrikse, G.W.J., Van Oijen, A.A.C.J. (2007). Accommodating two worlds in one organization: Changing board roles in agricultural cooperatives. International Society for New Institutional Economics. Reykjavik, Iceland.

Borgen, S.O. (2001). Identification as a trust-generating mechanism in cooperatives. Annals of Public and Cooperative Economics, 72, 208-228.

Bravo-Ureta, B.E., Lee, T.C. (1988). Socioeconomic and technical characteristics of New England dairy cooperative members and non-members. Journal of Agricultural Cooperation, 3, 12-27.

Burt, L., Wirth, M.E. (1990). Assessing the effectiveness of a farm supply cooperative: A comparison of farmer and manager viewpoints. Journal of Agricultural Cooperation, $5,17-26$.

Cain, J.L., Toensmeyer, U.C., Ramsey, S. (1989). Cooperative and proprietary firm performance as viewed by their customers. Journal of Agricultural Cooperation, 4, 81-88.

Chaddad, F.H., Cook, M.L. (2004). Understanding new cooperative models: An ownership-control rights typology, Review of Agricultural Economics, 26, 346-360.

Enander, J., Melin, A., Nilsson, J. (2009). Social influences in forest owners' choice between cooperative and investor-owned buyers. http://pub-epsilon.slu.se/1257/

Fahlbeck, E. (2007). The horizon problem in agricultural cooperatives - only in theory? In K Karantininis and J Nilsson (Ed.), Vertical markets and cooperative hierarchies (pp. 255-274). Dordrecht: Springer.

Fulton, J.R., Adamowicz, W.L. (1993). Factors that influence the commitment of members to their cooperative organization. Journal of Agricultural Cooperation, 8 , $39-53$

Furubotn, E., Pejovich, S. (1972). Property rights and economic theory: A survey of recent literature. Journal of Economic Literature, 10, 1137-1162.

Golovina, S., Nilsson, J. (2009). Difficulties for the development of agricultural cooperatives in Russia: The case of the Kurgan region, Journal of Rural Cooperation, $37,52-70$.

Gray, T.W., Kraenzle, C.A. (1998). Member participation in agricultural cooperatives: A regression and scale analysis. RBS Research Report 165. US Department of Agriculture, Rural Business - Cooperative Service, Washington DC.

Hakelius, K. (1999). Farmer cooperatives in the $21^{\text {st }}$ century: Young and old farmers in Sweden. Journal of Rural Cooperation, 27, 31-54.

Hansen, M.H., Morrow, J.L. Jr., Batista, J.C. (2002). The impact of trust on cooperative membership retention, performance and satisfaction: An exploratory study. International Food and Agribusiness Management Review, 5, 41-59.

Hendrikse, G.W.J. (2005). Contingent control rights in agricultural cooperatives, in T. Theurl and E.C. Meijer (Ed.), Strategies for cooperation (385-394), Shaker Verlag, Aachen. 
Hogeland, J.A. (2006). The economic culture of U.S. agricultural cooperatives. Culture \& Agriculture, 28, 67-79.

James, Jr. H.S., Sykuta, M.E. (2006). Farmer trust in producer- and investor-owed firms: Evidence from Missouri corn and soybean producers. Agribusiness: An International Journal, 22, 135-153.

Jensen, K. (1990). Factors associated with the selection of cooperative vs. proprietary handlers of milk in Tennessee. Journal of Agricultural Cooperation, 5, 27-35.

King, R.P. (1995). The future of agricultural cooperatives in North America: Discussion. American Journal of Agricultural Economics, 77, 1160-1161.

Klein, K.K., Richards, T.J., Walburger, A. (1997). Determinants of co-operative patronage in Alberta. Canadian Journal of Agricultural Economics, 45, 93-110.

Krstevska, A., Nilsson, J. (2009). Conditions for structural change in the Macedonian dairy industry. The dairy farmers' choice of processors. Paper presented at the 4th international conference on Economics and Management of Networks, at University of Sarajevo, Bosnia and Herzegovina.

Lang, K.A. (2006). Cognition, agency theory and organizational failure: A Saskatchewan Wheat Pool case study. Mater thesis, University of Saskatchewan, Saskatoon.

Laursen, C.V. (2005). Member satisfaction and participation in modern Danish cooperatives - a comparative analysis of the organizational characteristics of Arla Foods, Danish Crown and DLG. Mater thesis. The Royal Veterinary and Agricultural University, Food and Resource Economics Institute (FOI), Frederiksberg, Denmark.

Michels, R. (1968[1911]). Political parties: a sociological study of the oligarchical tendencies of modern democracy. New York: Free Press.

Misra, S.K., Carley, D.H., Fletcher, S.M. (1993). Dairy farmers' evaluation of dairy cooperatives. Agribusiness: An International Journal, 9, 351-361.

Nilsson, J., Ohlsson, C. (2007). The New Zealand dairy cooperatives' adaptation to changing market conditions. Journal of Rural Cooperation, 35, 43-70.

Nilsson, J., Kihlén, A., Norell, L. (2009). Are traditional cooperatives an endangered species? About shrinking satisfaction, involvement and trust, International Food and Agribusiness Management Review, 12, 103-123.

Österberg, P., Nilsson, J. (2009). Members' perception of their participation in the governance of cooperatives: The key to trust and commitment in agricultural cooperatives. Agribusiness: An International Journal, 25, 181-197.

Richards, T.J., Klein, K.K., Walburger, A. (1998). Principal-agent relationships in agricultural cooperatives: An empirical analysis from rural Alberta. Journal of Cooperatives, 13, 21-33.

Rydberg, C. (2009). Changing Fonterra's ownership model? Changing Fonterra's ownership model? Master thesis 564, Department of Economics, Swedish University of Agricultural Sciences, Uppsala.

Stryjan, Y. (1989). Impossible organizations: Self-management and organizational reproduction. New York: Greenwood.

Tönnies, F. (1957[1887]). Community and society. New York: Harper \& Row.

Van Bekkum, O.F., Bijman, J. (2006). Innovations in cooperative ownership: Converted and hybrid listed cooperatives. Paper presented in $7^{\text {th }}$ International Conference of Managemeng in AgriFood Chains and Networks, Ede, Netherlands, May 31-June 1. 
Van der Krogt, D., Nilsson, J., Høst, V. (2007). The impact of cooperatives' risk aversion and equity capital constraints on their inter-firm consolidation and collaboration strategies - with an empirical study of the European dairy industry. Agribusiness: An International Journal, 23, 452-472. 


\section{Publications in the ERIM Report Series Research* in Management}

\section{ERIM Research Program: "Organizing for Performance"}

\section{9}

On the Specification of the Gravity Model of Trade: Zeros, Excess Zeros and Zero-Inflated Estimation

Martijn J. Burger, Frank G. van Oort, and Gert-Jan M. Linders

ERS-2009-003-ORG

http://hdl.handle.net/1765/14614

The Current State of Research on Networks in China's Business System

Johannes Meuer and Barbara Krug

ERS-2009-007-ORG

http://hdl.handle.net/1765/14842

Encountered Problems and Outcome Status in Nascent Entrepreneurship

A. Marco van Gelderen, B. Pankaj Patel, and A. Roy Thurik

ERS-2009-008-ORG

http://hdl.handle.net/1765/14913

The Ethics of Organizations: A Longitudinal Study of the U.S. Working Population

Muel Kaptein

ERS-2009-018-ORG

http://hdl.handle.net/1765/15405

From Symbolic to Substantive Documents: When Business Codes of Ethics Impact Unethical Behavior in the Workplace Muel Kaptein

ERS-2009-021-ORG

http://hdl.handle.net/1765/15909

Knowledge Management as a Strategic Tool to Foster Innovativeness of SMEs

Haibo Zhou, and Lorraine Uhlaner

ERS-2009-025-ORG

http://hdl.handle.net/1765/15913

Knowledge Management in the SME and its Relationship to Strategy, Family Orientation and Organization Learning Haibo Zhou, and Lorraine Uhlaner

ERS-2009-026-ORG

http://hdl.handle.net/1765/15914

Defining Respectful Leadership: What it is, how it can be measured, and another glimpse at what it is related to Niels van Quaquebeke, and Tilman Eckloff ERS-2009-027-ORG

http://hdl.handle.net/1765/15942

Blue Ocean versus Competitive Strategy: Theory and Evidence

Andrew Burke, André van Stel, and Roy Thurik

ERS-2009-030-ORG

http://hdl.handle.net/1765/16037

Pattern matching

Tony Hak and Jan Dul

ERS-2009-034-ORG

http://hdl.handle.net/1765/16203

Replication

Tony Hak and Jan Dul

ERS-2009-035-ORG

http://hdl.handle.net/1765/16204 
Theory-Building With Cases

Tony Hak and Jan Dul

ERS-2009-036-ORG

http://hdl.handle.net/1765/16205

Theory-Testing With Cases

Tony Hak and Jan Dul

ERS-2009-036-ORG

http://hdl.handle.net/1765/16206

Functional Polycentrism and Urban Network Development in the Greater South East UK: Evidence from Commuting Patterns, 1981-2001

B. de Goei, M.J. Burger, F.G van Oort, and M. Kitson

ERS-2009-038-ORG

http://hdl.handle.net/1765/16213

On the Economic Foundation of the Urban Network Paradigm: Spatial Integration, Functional Integration and Economic Complementarities within the Dutch Randstad

F.G. van Oort, M.J. Burger, and O. Raspe

ERS-2009-039-ORG

http://hdl.handle.net/1765/16214

Gender Pay Differences in the European Union: Do Higher Wages Make Up For Discrimination?

Erik Canton and Ingrid Verheul

ERS-2009-041-ORG

http://hdl.handle.net/1765/16215

What do We Know about Social Entrepreneurship: An Analysis of Empirical Research

Brigitte Hoogendoorn, Enrico Pennings, and Roy Thurik

ERS-2009-044-ORG

http://hdl.handle.net/1765/16558

Developing Innovative Competences in an Emerging Business System: New Private Enterprises in Hangzhou's Software Industry

Mark Greeven and Zhao Xiaodong

ERS-2009-045-ORG

http://hdl.handle.net/1765/16599

From Inaction to External Whistleblowing: The Influence of the Ethical Culture of Organizations on Employee Responses to Observed Wrongdoing

Muel Kaptein

ERS-2009-047-ORG

http://hdl.handle.net/1765/16600

What Turns Knowledge into Innovative Products? The Role of Entrepreneurship and Knowledge Spillovers

Joern H. Block, Roy Thurik, and Haibo Zhou

ERS-2009-049-ORG

http://hdl.handle.net/1765/16769

The X-Factor: On the Relevance of Implicit Leadership and Followership Theories for Leader-Member Exchange (LMX)

Agreement

Suzanne van Gils, Niels van Quaquebeke, and Daan van Knippenberg

ERS-2009-055-ORG

http://hdl.handle.net/1765/17429

Entrepreneurial Finance in France: The Persistent Role of Banks

Sylvie Cieply and Marcus Dejardin

ERS-2009-056-ORG

http://hdl.handle.net/1765/17430 
Spatial Structure and Productivity in U.S. Metropolitan Areas

Evert Meijers and Martijn Burger

ERS-2009-057-ORG

http://hdl.handle.net/1765/17431

Gemeinschaft and Gesellschaft in Cooperatives

Jerker Nilsson and George Hendrikse

ERS-2009-059-ORG

http://hdl.handle.net/1765/17528

* A complete overview of the ERIM Report Series Research in Management: https://ep.eur.nl/handle/1765/1

ERIM Research Programs:

LIS Business Processes, Logistics and Information Systems

ORG Organizing for Performance

MKT Marketing

F\&A Finance and Accounting

STR Strategy and Entrepreneurship 